\title{
Analisis kebutuhan guru pendidikan jasmani, olahraga dan kesehatan pasca program guru pembelajar
}

\author{
Herka Maya Jatmika *, Awan Hariono, Joko Purwanto, Caly Setiawan \\ Fakultas IImu Keolahragaan, Universitas Negeri Yogyakarta \\ *Corresponding Author. Email: herka_mayajatmika@uny.ac.id
}

\begin{abstract}
Abstrak
Penelitian ini bertujuan untuk memetakan kompetensi guru serta rumusan rekomendasi kebijakan yang mendalam dan kongkrit mengenai konsep strategi implementasi kerja yang efektif, efisien, produktif, kreatif dan inovatif demi terlaksananya program pembinaan kompetensi dan profesionalitas guru secara khusus di Daerah Istimewa Yogyakarta. Penelitian ini merupakan penelitian deskriptif kualitatif yang bersifat eksploratif reflektif. Subjek Penelitian adalah para guru PJOK di jenjang Sekolah Dasar di Yogyakarta sebanyak 30 guru yang dipilih melalui mekanisme purposive. Proses pengumpulan data akan dibantu dengan lembar-lembar identifikasi atau pencatatan. Mekanisme pengumpulan data yang selanjutnya adalah dengan melakukan FGD dengan beberapa guru yang juga ditentukan melalui mekanisme purposive. Sementara itu, langkah-langkah yang hendak diterapkan dalam metode analisis data berturut-turut berupa, (1) klasifikasi data; (2) display data; (3) melakukan penafsiran dan interpretasi serta pengambilan kesimpulan. Guru PJOK di Daerah Istimewa Yogyakarta masih terkendala oleh kapasitas IT, kejelasan program Guru Pembelajar serta rendahnya pendampingan dari instansi terkait, sehingga dalam melaksanakan program ini mereka mengalamai stagnasi. Community based learning menjadi metode yang diingini oleh para guru PJOK dalam mengembangan kompetensinya. Konsep The Five Disciplines dari Peter Senge yang meliputi personal mastery, mental models, building shared vision, team learning, dan system thinking perlu didorong dalam upaya menghebatkan para guru PJOK.
\end{abstract}

Kata Kunci: analisis kebutuhan guru PJOK, program guru pembelajar

\section{Needs analysis for the sport and health education teachers after the implementation of learning-teacher program}

\section{Abstract}

The study aims at mapping the in-depth and concrete teacher competence and recommendation formula toward the concept of effective, efficient, productive, creative and innovative job implementation in implementing the special program of teachers' competence and professionalism development in the Province of Yogyakarta Special Region. The study is a qualitative descriptive research with explorative-reflective nature. When the study was conducted, the subjects were 30 teachers of Sports and Health Education in the Elementary Schools degree throughout the Province who had been selected by means of purposive sampling technique. Then, the data in the study were gathered bt means of identification or record sheets. After the data had been gathered, a focus group discussion (FGD) was conducted by involving several teachers who had also been selected by means of purposive sampling technique. Then, in analysing the data for the study the following procedures were applied: (1) data classification; (2) data display; (3) interpretation and conclusion drawing/verification. Based on the results of the study, it might be concluded that the teachers of Sports and Health Education in the Province of Yogyakarta Special Region are still troubled with their capacity of operating Information Technology, the clarity of LearningTeacher Program and the low guidance provided by the relevant institution; as a result, the implementation of the program among the teachers become stagnant. The teachers in the 
program prefer Community-Based Learning as the method for the program implementation. In relation to the demand, the concept of Five Disciplines by Peter Senge that includes personal mastery, mental models, building shared vision, team learning and system thinking should be encouraged in empowering the teachers of Sports and Health Education.

Keywords: needs analysis of the teachers of sports and health education, learning-teacher program

\section{PENDAHULUAN}

Telah dipahami bahwa guru PJOK dalam format sistem dan aplikasi pendidikan merupakan unsur yang berkontribusi signifikan bagi terwujudnya proses pembelajaran dalam konsepsi pendidikan yang bermutu. Disisi lain, mutu dalam konteks pendidikan merupakan akumulasi dari mutu masukan, mutu proses, mutu keluaran dan mutu dampak pendidikan dalam kehidupan masyarakat. Mutu masukan dapat dilihat dari beberapa sisi. Pertama, kualitas sumber daya manusia dalam hal ini guru PJOK dalam melayani pembelajaran pada satuan pendidikan; Kedua, mutu masukan material berupa kurikulum, buku, alat peraga, sarana dan prasarana sekolah; Ketiga, mutu perangkat lunak berupa peraturan, diskripsi kerja, struktur organisasi sekolah; Keempat, mutu masukan yang bersifat harapan dan kebutuhan, tercermin dalam visi-misi, semangat, kinerja, dan cita-cita dalam penyelenggaraan pendidikan.

Hasil kajian terhadap beberapa literatur menunjukkan adanya beberapa elemen kapasitas untuk meningkatkan mutu pembelajaran PJOK di persekolahan, yaitu: (1) Guru PJOK yang profesional, dilihat dari aspek pengetahuan dan ketrampilan, (2) motivasi siswa, (3) Materi kurikulum, (4) kualitas dan tipe SDM yang mendukung proses pembelajaran di kelas yang dalam hal ini adalah guru PJOK, (5) kuantitas dan kualitas interaksi para pihak pada tingkat organisasi sekolah, (6) sumber-sumber marterial, dan (7) organisasi dan alokasi sumber-sumber sekolah ditingkat lembaga.

Kapasitas guru PJOK sebagai salah satu elemen pengampu penyelenggaraan pendidikan bermutu terkait dengan bentuk tugas dan tanggungjawab kerjanya, yang dalam Peraturan Pemerintah Nomor 74 Tahun 2007 adalah merencanakan, melaksanakan dan melakukan penilaian pada penyelenggaraan pembelajaran di satuan pendidikan. Karena itu guru PJOK dengan peran profesionalnya menjadi unsur penting di antara unsur penting lainnya dalam menciptakan dan mengembangkan kegiatan dan proses pembelajaran di dalam dan/ atau di luar kelas. Peran tersebut berkembang dan semakin penting dalam era global ini yang semakin sarat dengan penguasan informasi dan teknologi maju. Kebutuhan guru PJOK dengan berbagai peran profesional seperti tersebut, mengalir sepanjang zaman seiring dengan tumbuh dan bertambahnya generasi baru yang harus dipersiapkan melalui pendidikan yang memadai sebagai generasi penerus bangsa.

Kenyataan nilai pentingnya peran guru PJOK dalam mewujudkan pelaksanaan pendidikan yang bermutu sebagaimana diuraikan, mengisyaratkan bahwa guru PJOK perlu diposisikan sebagai tenaga kerja dalam kualifikasi profesi yang sarat dengan: kompetensi, profesionalitas, komitmen kinerja, dan akuntabilitas dalam menjalankan tugasnya.

Sebagai perimbangan dari itu, untuk dapat menjalankan tugasnya dengan baik, guru PJOK perlu memperoleh jaminan atas pemenuhan kebutuhan dasarnya sebagai pekerja profesi berupa kesempatan pengembangan karier dan mutu profesionalitas, perlindungan dalam pengabdian profesi, penghargaan dan perlindungan atas prestasi kinerja, dan kelayakan kesejahteraannya. Konsekuensi dari kondisi tersebut, pemerintah berkewajiban melaksanakan pengembangan kebijakan dan program peningkatan mutu profesionalitas guru PJOK secara terencana dan sistematis.

Mencermati posisi dan peranan penting guru PJOK dalam upaya membangun pendidikan bermutu, kiranya perlu diajukan pertanyaan-pertanyaan pokok berkaitan dengan kondisi guru PJOK di Indonesia saat ini sebagai gambaran persoalan yang layak di ditindaklanjuti melalui kebijakan dan peraturan pemerintah tentang pembinaan dan pengelolaan guru PJOK yang sedang disiapkan, antara lain: (1) Sejauhmana guru PJOK diposisikan sebagai tenaga profesi setara profesi guru lain yang secara terpadu 
bertanggungjawab melaksanakan kegiatan pembelajaran sesuai dengan lingkup tugasnya guna merealisasikan pendidikan bermutu?; (2) Sejauh mana guru PJOK telah memenuhi kualifikasi sebagai tenaga profesional yang siap menangani tugas-tugas sesuai dengan bidang dan latar keilmuannya?; (3) Sejauhmana guru PJOK telah menunjukkan mutu profesionalitas yang dibutuhkan sebagai tenaga pendidik dalam proses pembelajaran di sekolah?; (4) Sejauhmana guru PJOK telah menunjukkan kinerja sesuai peran pentingnya secara aktif agar kegiatan belajar mengajar bisa berjalan dengan efektif dan efisien; (5) Sejauhmana guru PJOK telah diberi kesempatan dan fasilitasi untuk pengembangan karier, ilmu pengetahuan, dan ketrampilan pendukung keprofesionalannya?; (6) sejauhmana guru PJOK telah diberikan kepercayaan dan kesempatan untuk memberikan andil pendapat dalam penentuan kebijakan kependidikan?, (7) Sejauhmana tenaga kependidikan telah diberikan penghargaan atas prestasi kinerjanya?; (8) Sejauh mana guru PJOK telah diberikan perlindungan dalam pengabdian profesinya di dunia pendidikan; (9) Sejauhmana guru PJOK telah di berikan kelayakan kesejahteraan dalam pengabdiannya; (10) Sejauhmana guru PJOK telah memenuhi kebutuhan dan dikelola secara baik dalam penyelenggaraan pendidikan lingkup nasional menyangkut aspek pemerataan, perluasan akses, mutu, relevansi, daya saing (kemampuan berkinerja prima), tata kelola tenaga kependidikan, akuntabilitas, dan pencitraan?

Inti persoalan yang dapat ditarik dari analisa ini adalah bahwa elemen guru PJOK harus dikelola mutu kehidupan profesi dan penataan aksesibilitasnya secara terencana dan sistematis melalui acuan yang jelas, tegas, dan rinci. Uji Kompetensi Guru (UKG) merupakan salah satu acuan guru PJOK dalam meningkatkan kompetensinya. Melalui UKG seorang guru PJOK dapat mengetahui dimana posisi kompetensinya saat ini. UKG bagi guru PJOK merupakan cara mengukur kompetensi dasar tentang bidang studi PJOK (subject matter dan pedagogik dalam domain content). Kompetensi dasar bidang studi PJOK yang diujikan sesuai dengan bidang studi sertifikasi (bagi guru yang sudah bersertifikat pendidik) dan sesuai dengan kualifikasi akademik guru (bagi guru yang belum bersertifikat pendidik) (Kemendikbud, 2012). Pendekatan yang digunakan adalah tes penguasaan subject matter pada jenjang pendidikan tempat tugas guru.

Berkaca dari hasil UKG tahun 2012 hasil yang dicapai oleh guru PJOK belum menggembirakan dengan rata-rata 40.76, dengan rata-rata tertinggi dicapai oleh Provinsi DI Yogyakarta dengan rata-rata skor 46.04. Rata-rata skor ini menunjukkan bahwa kompetensi pedagogis dan profesional guru PJOK perlu mendapatkan perhatian dan upaya untuk meningkatkannya.

Data tersebut menunjukkan skor setiap grade guru PJOK peserta UKG berdasarkan jenjang pendidikan. Dari data tersebut dapat dilihat bahwa skor terbesar ada pada grade 5 . Dari data tersebut dapat disimpulkan bahwa jumlah guru PJOK yang menempati skor dibawah 50 lebih dari $50 \%$, atau dapat dikatakan bahwa kompetensi guru PJOK masih dibawah standar yang diharapkan.

Berdasarkan data tersebut, Provinsi DI Yogyakarta memiliki rata-rata skor UKG paling tinggi dibandingkan provinsi lain. Sampai saat ini belum diketahui mengapa guru di provinsi DI Yogyakarta mempunyai skor yang lebih baik dari provinsi lain. Hal ini karena belum dilakukannya analisis hasil UKG serta belum dipetakannya hasil UKG yang dapat berguna bagi pengambilan kebijakan berkaitan dengan upaya peningkatan kompetensi dan pengembangan karier guru PJOK di Provinsi DI Yogyakarta.

Tabel 1. Sebaran SKor UKG Jenjang SD, SMP, SMA, dan SMK

\begin{tabular}{|c|c|c|c|c|c|c|c|c|c|c|c|}
\hline \multicolumn{12}{|c|}{ Nilai UKG Guru PJOK } \\
\hline & \multicolumn{10}{|c|}{ Katagori } & \multirow{2}{*}{$\begin{array}{l}\text { Grand } \\
\text { Total }\end{array}$} \\
\hline No. Jenjang & $\leq 10$ & $10<x \leq 20$ & $20<x \leq 30$ & $30<x \leq 40$ & $40<x \leq 50$ & $50<x \leq 60$ & $60<x \leq 70$ & $70<x \leq 80$ & $80<x \leq 9$ & $0 \geq 90$ & \\
\hline 1. SD & 84 & 137 & 4822 & 19314 & 18386 & 9153 & 2966 & 504 & 101 & 57 & 55524 \\
\hline 2. SMP & 26 & 25 & 581 & 3903 & 7118 & 5713 & 2053 & 268 & 7 & - & 19694 \\
\hline 3. SMA & 9 & 5 & 188 & 1348 & 2915 & 2472 & 874 & 82 & 5 & - & 7900 \\
\hline 4. SMK & 2 & 1 & 75 & 634 & 1519 & 1582 & 686 & 77 & 2 & 3 & 4581 \\
\hline Jumlah & 121 & & 5,666 & 25,199 & 29,938 & 18,922 & 6,579 & 931 & 115 & 60 & 87,699 \\
\hline
\end{tabular}




\section{METODE}

Penelitian ini merupakan penelitian deskriptif kualitatif yang bersifat eksploratif reflektif. Subjek dalam penelitian ini adalah hasil capaian uji kompetensi guru PJOK tahun 2015. Pengumpulan data dilakukan melalui analisis data sekunder yang terlebih dahulu diseleksi melalui mekanisme purposive. Proses pengumpulan data akan dibantu dengan lembarlembar identifikasi atau pencatatan. Mekanisme pengumpulan data yang selanjutnya adalah dengan melakukan FGD dengan beberapa guru yang juga ditentukan melalui mekanisme purposive. Sementara itu, langkah-langkah yang hendak diterapkan dalam metode analisis data berturut-turut berupa, 1) klasifikasi data; 2) display data; 4) melakukan penafsiran dan interpretasi serta pengambilan kesimpulan (Kaelan, 2005: 68).

Terdata dua hal yang dicapai pada peneliyian ini yaitu, analisis mendalam mengenai hasil UKG tahun 2015 dan sistem peningkatan kompetensi dan pengembangan karir guru PJOK. Metode utama yang digunakan berupa penelitian kualitatif eksploratif reflektif dengn subjek primer hasil capaian UKG guru PJOK tahun 2015. Subjek sekunder adalah pada guru PJOK di Daerah Istimewa Yogyakarta yang di wawancarai dengan menggunakan mekanisme purposive. Sebanyak 30 guru PJOK SD yang telah melaksanakan UKG di Yogyakarta serta sebagai peserta aktif program guru pembelajar secara daring.

\section{HASIL DAN PEMBAHASAN}

\section{Hasil}

\section{Analisis Data Focus Group Discussion}

Sesuai dengan karakteristik analisis hasil UKG PJOK SD di Kota Yagyakarta, Hasil penelitian didasarkan pada dua aspek, yaitu hasil analisis data sekunder dari data hasil UKG dan analisis data primer melalui Diskusi Kelompok Terfokus (FGD) yang dilakukan bersama 30 guru PJOK SD yang telah melaksanakan UKG di Yogyakarta serta sebagai peserta aktif program guru pembelajar.

Hasil analisis berdasarkan data sekunder sesuai dengan deskripsi data tersebut dapat dijelaskan bahwa rata-rata skor yang dicapai oleh guru PJOK SD di Daerah Istimewa Yogyakarta sebesar 60,497 menunjukkan nilai yang cukup baik jika dilihat dari standar yang ditetapkan pemerintah sebesar 55. Hasil ini menggambarkan kompetensi guru PJOK pada unsur profesionalisme dan pedagogik meningkat dibandingkan hasil UKG tahun sebelumnya. Namun demikian hasil ini belum menunjukkan hasil memuaskan ketika kompetensi sebenarnya harus $100 \%$. Dengan kata lain bahwa harus terus diupayakan untuk meningkatkan kompetensi pasca UKG PJOK SD tahun 2015.

Hasil analisis berdasarkan FGD yang dilakukan berdasarkan diskusi mendalam dengan 25 orang guru dan 4 pakar pendidikan jasmani di Daerah Istimewa Yogyakrata. Adapun tabulasi data FGD dapat dilihat pada Tabel 2.

Tabel 2. Tema dan Cuplikan Pernyataan Responden

\begin{tabular}{|c|c|c|c|}
\hline No. & Tema & Sub Tema & Pernyataan Responden \\
\hline \multirow[t]{3}{*}{1.} & \multirow[t]{3}{*}{$\begin{array}{l}\text { Refleksi peserta } \\
\text { terhadap sistem } \\
\text { dan pelaksanaan } \\
\text { UKG }\end{array}$} & \multirow[t]{3}{*}{$\begin{array}{l}\text { Pemahaman dan } \\
\text { respon konseptual } \\
\text { terhadap UKG }\end{array}$} & $\begin{array}{l}\text { "kebanyakan guru tidak begitu yakin pak bahwa } \\
\text { UKG ini menjadi isntrumen yang serius untuk } \\
\text { memperbaiki kompetensi guru. Kalau bahasa yang } \\
\text { sering dimunculkan diteman-teman guru itu... } \\
\text { datang...kerjakan...kemudian lupakan.. ndak usah } \\
\text { dibawa repot pak..." }\end{array}$ \\
\hline & & & $\begin{array}{l}\text { "Kepala sekolah kami sempat berpesan...ndak perlu } \\
\text { risau.. yang penting paling tidak memperoleh skor } \\
\text { tidak dibawah 55..itu sudah aman" }\end{array}$ \\
\hline & & & $\begin{array}{l}\text { "Menghadapi UKG kami bersama teman-teman } \\
\text { secara rutin menggelar acara bedah kisi-kisi pak.. } \\
\text { tapi yaitu pak..kisi-kisi yang ada sebagian besar } \\
\text { kami dapat dari internet, ternyata semakin dipelajari } \\
\text { justru semakin membingungkan... Trus sebetulan } \\
\text { saya juga membeli dari seorang teman, sebuah }\end{array}$ \\
\hline
\end{tabular}


Jurnal Pendidikan Jasmani Indonesia, 13 (1), 2017 - 5

Herka Maya Jatmika, Awan Hariono, Joko Purwanto, Caly Setiawan

\begin{tabular}{|c|c|c|c|}
\hline \multirow[t]{2}{*}{ No. } & \multirow[t]{7}{*}{ Tema } & Sub Tema & Pernyataan Responden \\
\hline & & & $\begin{array}{l}\text { buku yang berisikan kisi-kisi test UKG pak, tebalnya } \\
\text { kurang lebih } 300 \text { an halaman. Tapi setelah saya } \\
\text { membaca.. lakok malah semakin pusing dan tidak } \\
\text { jelas..." }\end{array}$ \\
\hline & & \multirow[t]{5}{*}{$\begin{array}{l}\text { Refleksi tingkat } \\
\text { kesulitan dan } \\
\text { muatan soal }\end{array}$} & $\begin{array}{l}\text { "Soal-soal UKG tahun ini khususnya } \\
\text { kompetensi pedagogis lebih mengacu pada } \\
\text { kurikulum K13, padahal di sekolah kami masih } \\
\text { menggunakan KTSP, sehingga terus terang kami } \\
\text { merasa kesulitan" }\end{array}$ \\
\hline & & & $\begin{array}{l}\text { "Terus terang untuk guru-guru yang sudah di atas } \\
\text { usia } 45 \text { tahun seperti saya...banyak hal-hal baru } \\
\text { yang benar-benar saya tidak tahu..terutama terkait } \\
\text { dengan kompetensi profesional" }\end{array}$ \\
\hline & & & $\begin{array}{l}\text { "Nek kompetensi pedagogis itu menurut } \\
\text { sayaa...mau digonta ganti kurikulumnya toh tetep } \\
\text { sama pak... pada wilayah kompetensi profesional itu } \\
\text { yang berkembang dan banyak hal baru yang } \\
\text { kadang kita belum tahu..." }\end{array}$ \\
\hline & & & $\begin{array}{l}\text { "Saya itu merasa banyak yang bisa...dan yakin saya } \\
\text { itu bahwa bisa..tapi tahu tahu keluar hasil kok yang } \\
\text { benar Cuma sdikit.. terus terang saya malah } \\
\text { bingung.. tapi yaa mau gimana lagi pak, lawong } \\
\text { saya tidak bisa tahu di soal nomer berapa yang } \\
\text { salah je.." }\end{array}$ \\
\hline & & & $\begin{array}{l}\text { "Soal model uraian dengan illustrasi...terus terang } \\
\text { membuat kami bingung.. terkadang bagi kami } \\
\text { hubungan antara pernyataan dan pertanyaan susah } \\
\text { difahami... }\end{array}$ \\
\hline \multirow[t]{7}{*}{2.} & \multirow{7}{*}{$\begin{array}{l}\text { Permasalahan } \\
\text { teknis dalam } \\
\text { pelaksanaan } \\
\text { UKG }\end{array}$} & \multirow{5}{*}{$\begin{array}{l}\text { Informasi dan } \\
\text { Sosialisasi }\end{array}$} & "Informasi yang kami terima terkait pelaksanaan \\
\hline & & & $\begin{array}{l}\text { UKG seringkali sifatnya mendadak dan tidak } \\
\text { jelas...dan hanya ada beberapa orang saja ditingkat } \\
\text { bawah (kabupaten/ kecamatan) yang mempunyai } \\
\text { kewenangan.. jadinya kita justru paling seringnya } \\
\text { dapat informasi dari berita baik di koran maupun di } \\
\text { internet pak..dan rata-rata kok medeni ancamannya } \\
\text { itu... }\end{array}$ \\
\hline & & & $\begin{array}{l}\text { "Sosialisasi pelaksanaan UKG masih kurang begitu } \\
\text { jelas...teman-teman yaa ada yang menanggapi } \\
\text { serius pak..tapi yaa ada yang akhirnya terus luweh- } \\
\text { luweh..paling juga sama dengan program-program } \\
\text { yang lain, nanti ndak ada tindak lanjutnya. Demikian } \\
\text { sebagian teman-teman memahaminya pak.." }\end{array}$ \\
\hline & & & $\begin{array}{l}\text { "Kalau mendengar berita-berita yang dibicarakan } \\
\text { teman-teman...UKG itu benar-benar medeni pak.. } \\
\text { katanya kalau ndak lulus akan dihentikan } \\
\text { sertivikasinya..." }\end{array}$ \\
\hline & & & $\begin{array}{l}\text { "Semestinya pelaksanaan UKG untuk setiap bidang } \\
\text { studi bersamaan pak.. kalau seperti ini akhirnya } \\
\text { yang mendapat giliran belakangan yang mendapat } \\
\text { keuntungan" }\end{array}$ \\
\hline & & \multirow[t]{2}{*}{ Proses Test } & $\begin{array}{l}\text { "Terus terang kalau saya saat itu terganggu dengan } \\
\text { beberapa teman yang kebetulan berada didekat } \\
\text { saya...kebetulan ia ibu-ibu dan gaptek. Jadi bentar2 } \\
\text { tanya...dan akhirnya saya jadi ndak konsen deh } \\
\text { dengan test saya..padahal waktunya kan terbatas. }\end{array}$ \\
\hline & & & $\begin{array}{l}\text { "Tempat pelaksanaan test pengaturan tempatnya } \\
\text { sempit.. epet epetan mas, jadi agak tidak nyaman } \\
\text { untuk mengerjakan" }\end{array}$ \\
\hline
\end{tabular}


Jurnal Pendidikan Jasmani Indonesia, 13 (1), 2017 - 6

Herka Maya Jatmika, Awan Hariono, Joko Purwanto, Caly Setiawan

\begin{tabular}{|c|c|c|c|}
\hline No. & Tema & Sub Tema & Pernyataan Responden \\
\hline \multirow[t]{3}{*}{3.} & $\begin{array}{l}\text { Kebutuhan paska } \\
\text { UKG }\end{array}$ & $\begin{array}{l}\text { Konten (pedagogi, } \\
\text { pedagogi yang } \\
\text { spesifik penjas, } \\
\text { keterampilan PTK } \\
\text { dan menulis) }\end{array}$ & $\begin{array}{l}\text { "Waktu itu saya penerimaan waktu ilmu pedagogik } \\
\text { sangat terbatas." } \\
\text { "Apakah seperti ini caranya? Atau bagaimana cara } \\
\text { menganalisis, nanti ini bagaimana? Misalnya } \\
\text { penelitian tindakan kelas itu." } \\
\text { "Yang sangat kita butuhkan adalah untuk } \\
\text { menunjang profesi yang berkelanjutan ini } \\
\text { diadakannya pelatihan penulisan yang ada di } \\
\text { sekolah-sekolah." }\end{array}$ \\
\hline & & $\begin{array}{l}\text { Kritik model } \\
\text { pengembangan } \\
\text { profesi tradisional }\end{array}$ & $\begin{array}{l}\text { "Tidak perlu nunggu setahun sekali penataran yang } \\
\text { dilupakan satu bulan. Belum lagi nanti kalau } \\
\text { ditanya, ah mung koyo wingi kae. Materinya sudah } \\
\text { basi, membosankan, gurune di sana ngantuk." }\end{array}$ \\
\hline & & $\begin{array}{l}\text { Metode (COP, } \\
\text { Modul, Kemitraan) }\end{array}$ & $\begin{array}{l}\text { Jadi kalau saya punya group, katakanlah group } \\
\text { saya sendiri. } \\
\text { Ketika kita harus belajar, ya belajar tentang itu. Nah, } \\
\text { saran saya suatu saat nanti, itu ada modul-modul } \\
\text { baru. } \\
\text { Kemudian kita juga dijembatani dari misalnya kalau } \\
\text { kita itu dari penjas ya kita ya dijembatani universitas } \\
\text { terkait }\end{array}$ \\
\hline
\end{tabular}

Dua puluh lima dari 30 orang guru PJOK yang mengikuti FGD sepakat bahwa mereka mengalami kesulitan dalam melaksanakan sistem guru pembelajar yang dilakukan secara daring. Hal ini dipicu oleh keterbatasan kemampuan pengoperasian computer dan internet sebagaimana diungkapkan oleh Suparjinah guru PJOK di SD Tegalrejo I Kota Yogyakarta, "... saya memang mengajar di sd kota pak, tapi saya kan usianya sudah kepala 5 , 50an pak, kalau untuk urusan internet saya masih belum bisa, lawong UKG saja kemarin saya nunulnya banyak salah je pak, apalagi harus belajar on line, susah pak..hla mbok yo sekalian saja pemerintah apa dari UNY gitu pak ke kami memberikan buku dan ngasih semacam workshop malah dong kaminya pak". Lemahnya kemampuan IT juga dialami oleh Heri Prawaka guru PJOK di Pajangan Bantul yang juga mengeluhkan jika ia dan banyak rekan yang lain merasa kurang mampu dan malas untuk belajar lagi terkait dengan sistem guru pembelajar. Program guru pembelajar dinilai tidak lebih dari program yang hanya akan bertahan dalam hitungan jari, sehingga para guru merasa enggan untuk fokus di dalamnya. Asta guru di SD Ngentak Bantul menyampaikan bahwa:

"saya sudah belajar 2 modul dari 4 modul pak, tapi kabarnya program guru pembelajar akan digantikan dengan PKB, itu bener po pak? trus kapan akan dilaksanakan? seperti kurikulum ktsp diganti K13 trus kami juga minim sosialisasi dan dari dinas tidak melakukan pendampingan".

\section{Pembahasan}

Dari analisis data tersebut, secara tersirat dapat dikatakan bahwa guru memiliki pemahaman yang beragam tentang pengembangan profesi. Berdasar definisi secara luas, pengembangan profesi mencakup semua tipe pembelajaran profesional yang dilakukan oleh guru terhitung mulai dari saat kelulusan dari program pendidikan keguruan strata 1 atau setelah mengikuti pendidikan keguruan seperti SGO dan D-2/3/4 (Armour \& Yelling, 2004). Walaupun mereka mengerti berbagai kegiatan yang mencakup pengembangan profesi, mereka belum sepenuhnya memahami secara konseptual pengembangan profesi, terlebih lagi pengembangan profesi berkelanjutan. Secara khusus, pengembangan profesi yang berkelanjutan semestinya mengakar pada pembelajaran guru (Armour \& Yelling, 2007). Artinya, memfokuskan tentang bagaimana guru belajar untuk memperkaya dan memperbaharui kepasitasnya sebagai guru. Kelemahan ini ditambah dengan kurangnya pemahaman yang memadai tentang kaitannya UKG dan pengembangan profesi berkelanjutan (PKB). Data menunjukkan bagaimana guru lebih menempatkan UKG sebagai syarat dan harus dipersiapkan secara khusus dalam menghadapi test. Seyogyanya, UKG 
mesti diperlakukan sebagai cermin yang dengan apa adanya merefleksikan kondisi kekinian kompetensi guru. Setelah UKG adalah, guru perlu melakukan pengembangan keprofesian secara berkelanjutan yang orientasi akhirnya adalah pada pembelajaran siswa.

Pada titik ini yang diperlukan adalah apa teori pembelajaran untuk guru ini dan bagaimana mereka mesti belajar sebagai proses pengembangan profesi mereka. Salah satu landasan teori dalam pengembangan profesi berkelanjutan adalah pembelajaran yang disituasikan (situated learning). Pembelajaran yang disituasikan adalah bentuk pengembangan dari teori konstruktivisme dalam pembelajaran (Kirk \& MacDonald, 1998). Pendekatan konstrustivisme menekankan bahwa pembelajaran merupakan proses aktif, konstruktif, kumulatif, berorientasi pada tujuan, diagnostic, dan reflektif (Simons, 1993). Dengan kata lain, proses belajar berlangsung bukan karena sesorang yang berpengetahuan memberikan informasinya secara searah kepada yang dianggap tidak berpengetahuan. Namun, proses belajar berlangsung karena pembelajar mengkonstruksi pengetahuan berdasar apa yang sudah diketahuinya dan terus menerus sehingga menjadi suatu bangunan pengetahuan. Dengan mendasarkan pada pendekatan konstruktivisme inilah, pembelajaran yang disituasikan mengembangkan konstrukstivisme yang bersifat individual menjadi bersifat sosial dan kontekstual. Kirk dan MacDonald (1998) menyatakan bahwa dalam pengertian pembelajaran yang disituasikan, pembelajaran mengambil tempat di dalam konteks sosio kultural dan dipengaruhi oleh konteks tersebut. Kesimpulannya, pembelajaran adalah "suatu proses aktif dan kreatif yang melibatkan interaksi individu dengan lingkungan dan pembelajar lainnya (Kirk \& MacDonald, 1998, hal. 377)." Peserta diskusi memahami pendekatan pembelajaran apa yang tepat untuk mereka sendiri. Data menunjukkan pentingnya pembelajaran yang sifatnya terus menerus berdasarkan apa yang sudah mereka miliki.

Konsep lain pembelajaran yang disituasikan adalah apa yang disebut sebagai pengakuan pertisipasi pinggiran dan komunitas praktis. Penjabaran dari ide pokok ini adalah bahwa seorang sarjana yang baru saja lulus pendidikan keguruan kemudian memasuki dunia kerja. Dalam dunia kerja ini ada suatu komunitas guru pendidikan jasmani yang secara sosial memiliki norma, tingkah laku, pilihan bahasa, dan cara berkomuniasi. Orang baru dalam komunitas kemungkinan besar akan kaku dan kikuk saat pertama kali bergabung. Inilah yang disebut sebagai partisipasi pinggiran. Dalam konsep ini, pembelajaran yang disituasikan memberikan pengakuan terhadap "orang baru" dan membimbing untuk masuk dalam komunitas, terlibat dalam pembicaraan, menyumbang ide, dan berbagai kegiatan lainya yang membantu orang baru tersebut untuk bergerak menuju pusat komunitas praktis. Pada titik inilah pembelajaran berlangsung dari dan oleh sesama anggota komunitas. Oleh sebab itu, pembelajaran yang disituasikan memiliki arti penting sebagai dasar teori karena konsep pengembangan profesi yang berkelanjutan mestinya berlangsung di dalam komunitas praktis guru pendidikan jasmani (Borko, 2004; Parker, Patton, Madden, \& Sinclair, 2010; Putnam \& Borko, 2000). Konsep ideal PKB ini menjadi aspirasi para guru peserta diskusi yang menganggap peran komunitas praktis seperti KKG dan MGMP adalah hal yang penting sebagai apa yang secara teoritik disebut sebagai pembelajaran yang disituasikan (situated learning).

Hasil analisis data menujukkan bahwa guru-guru mengeluhkan pengembangan profesi yang tidak bersifat terus menerus atau berkelanjutan. Dalam melakukan berbagai aktifitas pengembangan profesi, seorang guru biasanya melakukan beragam aktivitas yang tidak jarang antara satu aktivitas dengan yang lain tidak berkaitan sama sekali atau bahkan saling bertentangan. Ini hal yang lumrah dan tidak bisa dihindari karena penyelenggara kegiatan pengembangan profesi di luar kuasa dan kendali guru. Apa yang bisa dilakukan oleh guru adalah menemukan apa yang disebut kombinasi berbagai kegiatan yang optimal (optimal mix) dari pengembangan profesi untuk guru dari berbagai latar konteks (Armour \& Yelling, 2007). Selain itu, pengembangan profesi model baru seharusnya mencakup perspektif individu dan organisasi, berpikiran secara luas namun memulai langkah dari hal kecil, kerjasama tim, umpan balik (feedback) secara terus menerus, dan hal baru yang dipelajari harus diintegrasikan dalam praktis. 
Apapun yang dilakukan guru dalam mengembangkan profesi seyogyanya memiliki dampak pada pembelajaran siswa. Kita sering mendengar slogan dari berbagai penyelenggaran pelatihan bahwa misi mereka adalah hendak merubah sikap, perilaku, dan cara guru mengajar. Asumsi merubah praktik mengajar guru ini sudah saatnya dibenahi. Kini saatnya, menurut Guskey (1995) sebagai mana dikutip oleh Armour dan Yelling (2007), penyelenggara kegiatan pengembangan profesi untuk menyadari bahwa guru hanya akan berubah secara signifikan setelah mereka mendapatkan bukti atas meningkatnya pembelajaran murid-murid mereka.

Mengkaitkan kegiatan pengembangan profesi dengan pembelajaran siswa bukanlah tugas mudah. Penelitian dalam bidang pengembangan profesi juga miskin teori yang menjelaskan bagaimana pengembangan profesi berdampak pada siswa. Penelitian oleh Armour dan Yelling (2007) pun hanya menggali pembelajaran guru. Namun, dalam praktik pengembangan profesi dan pengumpulan data mereka, guru diminta secara berkelajutan dan terus menerus mereflesikan apa yang telah mereka pelajari. Kedua peneliti ini menyimpulkan bahwa guru pendidikan jasmani "menilai secara positif pembelajaran professional (guru) secara kolaboratif karena mereka merasakan bahwa hasil pembelajaran mereka dapat diterapkan untuk siswa mereka dan pada konteks sekolah mereka" (Armour \& Yelling, 2007, p. 181). Data menunjukkan bahwa peserta merasakan perlunya konten yang berkaitan dengan pengembangan pedagogi mereka dalam mengajar pendidikan jasmani. Hal ini justru menunjukkan bahwa apapun kegiatan PKB harus berdampak pada perubahan mereka mengajar. Pada gilirannya, mereka berharap akan mengimbas pada efektifitas murid belajar.

Ada banyak faktor yang menentukan apakah suatu kegiatan pengembangan profesi memiliki efektifitas. Untuk mendiskripsikan faktor-faktor tersebut saya akan meminjam klasifikasi yang dilakukan oleh Garret, Porter, Desimone, Birman, dan Yoon (2001) saat mereka melakukan penelitian efektifitas pengembangan profesi guru matematika dan ilmu pengetahuan alam. Faktor-faktor tersebut meliputi ciri struktural, ciri inti, dan koherensi. Alinea di bawah ini merupakan penjabaran dari faktor tersebut sebagaimana analisis data focus group discussion merujuk pada aspirasi guru yang merujuk pada ciri-ciri tersebut.

Ciri struktural PKB yang efektif meliputi tipe aktifitas, durasi, dan partisipasi secara kolektif. Berdasar tipe aktifitas, secara umum kegiatan pengembangan profesi dalam bentuk pelatihan, lokakarya, kuliah, seminar, dan konferensi. Ciri-ciri umum dari kegiatan tersebut adalah disampaikan oleh ahli dan guru hadir sebagai peserta sesuai jadwal yang ditentukan. Berbagai jenis pengembangan profesi ini sering dikritisi karena tidak efektif dalam mengembangkan profesi guru karena mengambil tempat di luar sekolah dan ruang kelas sehingga tidak mendekatkan guru dengan konteks profesi mereka. Selain itu, kegiatan pengembangan profesi tersebut juga memiliki waktu, materi, dan aktivitas yang memadai untuk meningkatkan pengetahuan guru dan mendorong perubahan yang bermakna di dalam praktik mengajar. Tentu saja pandangan peserta diskusi tentang tipe aktifitas masih belum merefleksikan konsep tersebut. Namun kita bisa menarik benang merah bahwa guru beraspirasi PKB yang selama ini di luar konteks mereka. Data menunjukkan kompetensi apa yang mereka ingin kuasai dan hal ini terkait dengan perubahan bermakna tentang cara mengajar mereka.

Lantas bagaimana aspirasi guru ini mesti diejawantahkan? Garret dkk (2001) mengidentifikasi ciri-ciri umum pengembangan profesi yang efektif diantaranya melalui kegiatan mentoring dan coaching. Berbeda dengan kegiatan pengembangan profesi traditsional, walaupun Borko (2004) berargumen untuk tidak selalu dilakukan di sekolah, kegiatan ini mengambil tempat di sekolah dan dilaksanakan selama jam sekolah tersebut. Selain itu, mentoring dan coaching dilaksanakan, setidaknya sebagian dari kegiatan, selama proses pembelajaran siswa di kelas dan sesuai dengan rencana kegiatan guru yang sudah terjadwal. Dengan demikian kegiatan ini akan lebih kontekstual dan lebih mudah menjaga kelangsungannya. Selain itu, bentuk kegiatan dapat berupa kelompok belajar guru, jaringan atau kolaborasi guru, komite, magang, dan pusat informasi. Hal ini persis dengan keyakinan guru terhadap berbagai komunitas profesi sebagai media untuk mengejawantahkan kegiatan PKB yang efektif. 
Melengkapi uraian tersebut, Garret dkk (2001) menambahkan bahwa tipe aktivitas pengembangan profesi guru mesti lebih responsif terhadap bagaimana guru belajar, dapat mempengaruhi perubahan praktik mengajar, dan memperhatikan kebutuhan guru. Dengan berbagai tipe baru pengembangan profesi guru, manfaat bagi guru mencakup durasi waktu yang lebih lama dan mendorong partisipasi kelompok guru dari satu sekolah secara kolektif.

Hasil analisis jelas sekali menunjukkan bagaimana kegiatan pengembangan profesi selama ini kurang efektif ditinjau dari durasi kegiatan. Garret dkk (2001) mengidentifikasi pentingnya memikirkan ulang durasi kegiatan pengembangan profesi. Kegiatan yang lebih lama waktunya diharapkan akan semakin (1) memungkinkan tersedianya kesempatan untuk diskusi materi yang lebih mendalam, pemahaman baru tentang konsepsi dan mis-konsepsi siswa, dan strategi pedagogi dan (2) memungkinkan guru untuk mencoba hal baru dalam pengajaran mereka dan mendapatkan umpan balik. Selain itu, kegiatan dengan waktu yang memadai akan memberikan kesempatan bagi guru untuk belajar lebih mendalam, meningkatkan interaksi, dan memungkinkan refleksi.

Hampir semua responden mengamini peran komunitas praktis seperti KKG dan MGMP sebagai wahana yang potensial dalam mengembangkan profesi mereka. Hal ini karena kegiatan berbasis komunitas berpotensi kolektif. Kegiatan pengembangan profesi yang efektif disarankan untuk dirancang secara kolektif untuk guru yang berasal dari satu sekolah, satu departemen, atau bahkan satu kelas. Dengan rancangan kegiatan yang ditujukan untuk satu kelompok guru ini akan memberikan beberapa keuntungan. Pertama, guru yang bekerja secara bersama-sama lebih memiliki kemungkinan untuk mendapatkan kesempatan dalam berdiskusi tentang konsep, keterampilan, dan masalah yang muncul. Kedua, guru yang berasal dari satu tempat lebih memungkinkan untuk saling berbagi materi kurikulum, pembelajaran, dan evaluasi belajar siswa. Di dalam kelompok ini, guru akan mampu mengintegrasikan apa yang mereka pelajari dengan aspek instruksional yang lain. Ketiga, guru dengan siswa yang sama akan dapat mendiskusikan kebutuhan siswa di tiap-tiap jenjang kelas. Keempat, pengembangan profesi akan membantu keberlangsungan perubahan praktik mengajar secara terus menerus karena dengan desain kegiatan ini dapat mengembangakan budaya profesional dimana guru dalam satu sekolah atau guru yang mengajar kelas yang sama akan mengembangkan pemahaman bersama tentang tujuan instruksional, metode, masalah, dan solusi.

Selain ciri-ciri struktural, PKB yang efektif memiliki ciri-ciri utama, seperti memfokuskan pada materi, pengembangan belajar secara aktif, dan penerapan rencana pembelajaran. Tentang focus pada materi, isi materi kegiatan pengembangan profesi di Indonesia lebih cenderung bervariasi. Bahkan beberapa guru mengikuti beberapa kegiatan yang mungkin tidak ada kaitannya dengan pendidikan jasmani. Tentu bukan semata-mata salah guru tersebut. Tetapi karena penilaian kegiatan pengembangan profesi lebih berorientasi pada level kegiatan itu, seperti tingkat lokal, nasional, atau internasional. Selain itu, guru pendidikan jasmani juga sangat dikaitkan dengan olahraga secara umum dan berbagai kegiatan keolahragaan yang tidak ada kaitan dengan pengajaran pendidikan jasmani bisa terhitung nilai tinggi jika tingkatnya nasional ataupun internasional. Walaupun belum ada kesimpulan teoritik yang memberi informasi tentang efektifitas variasi materi, beberapa ahli menyarankan untuk memfokuskan isi materi yang dapat meningkatkan kinerja guru dalam mengajar. Fokus isi materi ini mencakup pengetahuan tentang isi mata pelajaran dan pemahaman tentang bagaimana siswa belajar isi materi tersebut (Garret, dkk, 2001). Nampak dari data bahwa aspirasi guru tentang tindak lanjut UKG adalah pada materi seperti yang disampaikan Garret, dkk (2001).

Hakekat PKB adalah pembelajaran guru. Pembelajaran secara andragogi semestinya menekankan pada pengembangan belajar secara aktif. Belajar secara aktif dapat dilakukan melalui beberapa jenis kegiatan, misalnya melakukan pengamatan guru senior mengajar atau mengajar dan diamati oleh rekan sejawat untuk mendapatkan masukan dan umpan balik. Secara lebih rinci, guru saling mengunjungi pengajaran mereka atau mendatangkan ahli untuk mengamati dan saling berdiskusi secara reflektif tentang tujuan dan strategi pembelajaran. Walaupun data tidak mengindikasikan konsep PKB ini, dapat ditafsirkan 
bahwa pembelajaran guru yang bersifat aktif akan menjadi terobosan penting dalam PKB mereka.

Hasil FGD menunjukkan bahwa responden mengeluhkan kegiatan PKB memiliki jarak antara teori dan praktis yang mengakibatkan lemahnya daya serap guru terhadap konten kegiatan pengembangan. Oleh sebab itu, PKB seyogyanya menerapkan rencana pembalajaran. Dalam suatu kegiatan pengembangan profesi, guru biasanya mendapatkan materi yang baru dan lebih sering di antara mereka mendapatkan kesulitan untuk menerapkannya di ruang kelas mereka. Salah satu wujud belajar secara aktif adalah dengan mendesain kegiatan dimana guru mendapatkan kesempatan untuk merancang pembelajaran dan kemudian menerapkan pengetahuan barunya itu dalam praktik pengajaran mereka. Secara teoritik, kegiatan ini akan menjembatani apa yang dipelajari dengan konteks guru tersebut bekerja.

Garret dkk (2001) menyatakan bahwa bagi guru kebermaknaan kegiatan pengembangan profesi dapat dirasakan jika kegiatan tersebut menjadi bagian dari koherensi pembelajaran guru. Beberapa ahli sering mengkritik tentang banyaknya kegiatan pengembangan profesi yang satu sama lainnya tidak memiliki kaitan, saling terpecah-pecah, dan sporadis. Demikian juga responden dalam penelitian ini mengeluhkan hal yang sama. Hal ini sering terjadi karena proses penilaian pengembangan profesi guru saat kenaikan pangkat cenderung tidak memperhatikan isi kegiatan dan lebih fokus pada level dan reputasi kegiatan atau penyelenggara kegiatan tersebut. Garret dkk (2001) menegaskan bahwa koherensi dapat dicapai dengan tiga cara: "(1) dimana kegiatan tersebut dilaksanakan berdasar apa yang sudah dipelajari guru, (2) menekankan isi materi dan pedagogi yang sesuai dengan standar kurikulum nasional, dan (3) mendukung guru dalam mengembangkan komunikasi profesi dengan guru lain secara terus menerus dan berkelanjutan" (hal. 927).

\section{SIMPULAN}

Bagi kebanyakan guru, pemahaman UKG belum sepenuhnya dipahami sebagai media untuk cermin diri yang kemudian mesti ditindaklanjuti dalam bentuk program-program pengembangan profesi. Akibatnya, respon guru cenderung menanggapi test sebagai test sehingga apa yang mereka lakukan adalah mempersiapkan diri untuk menghadapi test dan meningkatkan keterampilan menjawab soal. Padahal, sesungguhnya bukan persoalan jika guru tidak harus belajar menghadapi UKG. Bagi mereka, yang perlu dilakukan adalah tindak lanjut setelah mengetahui kompetensi mereka yang ditunjukkan oleh skor hasil test. Program guru pembelajar bukannya tanpa kendala, di tingkat pelaksanaan oleh guru, guru mengalami kendala terkait dengan kemampuan IT, kejelasan program, pendampingan dari dinas terkait maupun dari akademisi. Sehingga, Perlu adanya kejelasan dan sosialiasi serta pendampingan secara berkala kepada para guru PJOK yang masuk dalam program guru pembelajar yang dilakukan oleh dinas terkait dan kalangan akademisi.Program Guru Pembelajar senyatanya merupakan program yang bagus bagi guru PJOK untuk senantiasa mengasah wawasannya, namun di tingkat pelaksanaan, guru PJOK membutuhkan pendampingan dalam selama mengikuti program tersebut serta modalitas dalam hal ini kemampuan IT serta perangkat penunjang layaknya internet dan komputer yang memadai vital untuk ada. Kementerian Pendidikan dan Kebudayaan, Dinas Pendidikan di tingkat Kabupaten serta Akademisi secara berkala memberikan pencerahan kepada para guru PJOK.

\section{DAFTAR PUSTAKA}

Armour, K. M. \& Yelling, M. R. (2004a). Continuing professional development for experienced physical education teachers: towards effective provision. Sport, Education, Society, 9(1), 95-114.

Armour, K. M. \& Yelling, M. R. (2004b). Profesional "development" and profesional "learning": bridging the gap for experienced physical education teacher. European Physical Education Review, 10(1), 71-93. 
Armour, K. M. (2006). Physical education teachers as career-long learners: a compeling research agenda. Physical Education \& Sport Pedagogy, 11(3), 203-207.

Armour, K. M. \& Yelling, M. (2007). Effective professional development for physical education teachers: the role of informal, collaborative learning. Journal of Teaching in Physical Education, 26, 177-200.

Borko, H. (2004). Profesional development and teacher learning: mapping the terrain. Educationa Researcher, 33(8), 3-15.

Garret, M. S., Porter, A. C., Desimone, L., Birman, B. F., Yoon, K S., (2001). What makes professional development effective? Results from a national sample of teachers. American Educational Research Journal, 38(4), 915-945.

Kaelan. (2003). Filsafat bahasa, masalah dan perkembangannya. cetakan ketiga, hlm:56.

Presiden Republik Indonesia. (2006). Undang-Undang Republik Indonesia Nomor 20 Tahun 2003 tentang sistem pendidikan nasional; Departemen Pendidikan Nasional Republik Indonesia, Biro Hukum dan Organisasi Sikjen Depdiknas, Jakarta.

Presiden Republik Indonesia. (2006). Undang-Undang Republik Indonesia Nomor 19 Tahun 2005 tentang standar nasional Pendidikan, Departemen Pendidikzan Nasional Republik Indonesia, Biro Hukum dan Organisasi Sikjen Depdiknas, Jakarta.

Peraturan Menteri PAN dan RB Nomor 16 Tahun 2009 tentang jabatan fungsional guru dan angka kreditnya; Departemen Pendidikzan Nasional Republik Indonesia, Biro Hukum dan Organisasi Sikjen Depdiknas, Jakarta.

Senge, S. (2006). The fifth discipline. The art and practice of the learning organization. $2^{\text {nd }}$ Edition.United States: Harvard.

Volmer, H. M., \& Mills, D. L (1966); Professionalization; Prentice-Hall, Inc, New Jersey.

World Education Report (1998); Teachers and teaching in a changing world; Paris UNESCO Publishing. 